\title{
IMPLEMENTASI MODEL PEMBELAJARAN KOOPERATIF TIPE THINK-PAIR- SHARE (TPS) UNTUK MENINGKATKAN KEMAMPUAN PEMECAHAN MASALAH MATEMATIS SISWA PADA MATERI SEGITIGA
}

\author{
Sri Lestari ${ }^{1}$, Nurma Angkotasan ${ }^{2}$, Hasriani Ishak ${ }^{3}$ \\ ${ }^{1,2,3}$ Program Studi Pendidikan Matematika, Universitas Khairun
}

\begin{abstract}
ABSTRAK
Penelitian ini merupakan penelitian eksperimen yang bertujuan untuk mengetahui: 1 . kemampuan pemecahan masalah matematis siswa kelas VII MTs Darul Ulum Sasa setelah menggunakan model pembelajaran kooperatif tipe Think-Pairs-Share. 2. penerapan model pembelajaran kooperatif tipe Think-Pairs-Share dapat meningkatkan kemampuan pemecahan masalah matematis siswa kelas VII MTs Darul Ulum Sasa. 3.Peningkatan kemampuan pemecahan masalah matematis siswa kelas VII MTs Darul Ulum Sasa dengan menggunakan model pembelajaran kooperatif tipe Think-Pairs-Share. Desain penelitian ini adalah OneGroup Preetest-Posttest Design eksperimen. Data hasil penelitian dianalisis menggunakan analisis deskriptif yaitu menggunakan kriteria kemampuan pemecahan masalah matematis siswa dan analisis inferensial yaitu uji normalitas sebagai uji prasyarat karena data yang diperoleh berdistribusi normal maka digunakan uji Paired t-test sebagai uji hipotesis.

Hasil penelitian menunjukkan bahwa: 1) kemampuan berpikir pemecahan masalah matematis siswa setelah diterapkan model pembelajaran kooperative tipe Think-Pairs-Share diperoleh 8 orang siswa berkualifikasi memuaskan, 2 orang siswa berkualifikasi baik, 6 orang siswa berkualifikasi cukup dan 4 orang siswa berkualifikasi kurang serta 5 orang siswa berkualifikasi gagal. 2) model pembelajaran kooperatif tipe NHT meningkatkatkan kemampuan pemecahan masalah matematis siswa siswa, Pengujian hipotesis digunakan Paired t-test diperoleh hitung=3,99 tabel= 1,711 karena hitung $>$ tabel, sehingga Ho ditolak dan H1 diterima. Dengan demikian model pembelajaran kooperatif tipe TPS dapat meningkatkan kemampuan pemecahan masalah matematis. Hasil analisis peningkatan kemampuan pemecahan masalah matematis dengan menggunakan uji Gain berinterprestasi sedang.
\end{abstract}

Kata Kunci: Model Pembelajaran Kooperatif Tipe tipe Think-Pairs-Share, kemampuan pemecahan masalah matematis 


\section{PENDAHULUAN}

Pendidikan adalah usaha sadar dan bertujuan untuk mengembangkan kualitas sumber daya manusia. Sebagai suatu kegiatan yang sadar akan tujuan, maka dalam pelaksanaannya berada dalam suatu proses yang berkesinambungan dalam setiap jenis dan jenjang pendidikan. Semuanya berkaitan dalam suatu sistem pendidikan yang integral. Pendidikan sebagai sistem, tidak lain dari suatu totalitas fungsional yang terarah pada suatu tujuan. Setiap subsistem yang ada dalam sistem tersusun dan tidak dapat dipisahkan dari rangkaian unsur-unsur atau komponen-komponen yang berhubungan secara dinamis dalam suatu kesatuan (Djamarah, 2010: 22). Selain itu juga diartikan sebagai sebuah proses dengan metode-metode tertentu sehingga orang memperoleh pengetahuan, pemahaman, dan cara bertingkah laku yang sesuai dengan kebutuhan (Syah, 2003: 10).

Matematika merupakan salah satu bidang studi yang menduduki peran penting dalam dunia pendidikan, hal ini dapat dilihat dari waktu jam pelajaran sekolah lebih banyak dibandingkan pelajaran lain. Pada umumnya, matematika sering dianggap sebagai mata pelajaran yang sulit dipahami (Mufidah, 2013: 118). Tujuan pembelajaran matematika bukan hanya mengalihkan pengetahuan matematika kepada siswa, tetapi juga mengembangkan potensi yang ada pada siswa dan memiliki keterampilan pengetahuan tersebut sehingga memungkinkan terjadinya perubahan pada pola pikir siswa (Marlina dkk., 2014: 84). Sesuai National Council of Teachers of Mathematics (NCTM) (Fauziah, 2010: 1) menyatakan bahwa standar matematika sekolah haruslah meliputi standar isi dan standar proses. Standar proses meliputi pemecahan masalah, penalaran dan pembuktian, keterkaitan, komunikasi, dan representasi. Sumarmo (Fauziah, 2010: 1) menyatakan bahwa kemampuan-kemampuan itu disebut dengan daya matematik (mathematical power) atau keterampilan bermatematika (doing math). Salah satu doing math yang erat kaitannya dengan karakteristik matematika adalah kemampuan pemecahan masalah. Pemecahan masalah merupakan hal yang sangat penting sehingga menjadi tujuan umum pengajaran matematika bahkan sebagai jantungnya matematika. Proses berpikir dalam pemecahan masalah memerlukan kemampuan mengorganisasikan strategi.

Hal ini akan melatih orang berpikir kritis, logis, kreatif yang sangat diperlukan dalam menghadapi perkembangan masyarakat. Berdasarkan hal tersebut, cara pembelajaran matematika harus diperbaharui guna meningkatkan pemecahan masalah matematis siswa menjadi lebih baik, untuk meningkatkan hal tersebut diperlukan sebuah model pembelajaran. Berbagai model pembelajaran yang berorientasi pada aktivitas siswa saat ini telah banyak dikemukakan. Salah satu model yang dapat digunakan untuk meningkatkan aktivitas belajar 
adalah model cooperative learning atau pembelajaran kooperatif. Pembelajaran kooperatif merupakan suatu model pembelajaran yang digunakan untuk proses belajar, dengan pembelajaran kooperatif siswa akan lebih mudah menemukan secara komprehensif konsepkonsep yang sulit jika mereka mendiskusikan dengan siswa yang lain tentang masalah yang dihadapi.

Model pembelajaran kooperatif terbagi atas beberapa tipe, salah satunya adalah Think Pair Share. Model pembelajaran kooperatif tipe Think Pair Share (TPS) adalah salah satu model pembelajaran yang cukup efektif untuk meningkatkan kemampuan pemecahan masalah matematis siswa karena siswa dituntut untuk melakukan aktivitas yang lebih banyak saat belajar. TPS memberikan kesempatan kepada siswa untuk bekerja sendiri serta bekerja sama dengan orang lain. Hasil penelitian Bubin (Husna dkk., 2013: 83) menunjukkan bahwa pembelajaran dengan menggunakan model kooperatif Think-Pair-Share dapat meningkatkan kemampuan pemecahan masalah matematis peserta didik.

\section{METODE PENELITIAN}

Metode dalam penelitian ini adalah penelitian eksperimen karena di dalamnya terdapat perlakuan. Metode penelitian eksperimen merupakan metode penelitian yang digunakan untuk mengetahui pengaruh treatment (perlakuan) tertentu. Treatment (perlakuan) yang dimaksud adalah tindakan berupa penerapan metode pembelajaran kooperatif Think-Pair-Share untuk meningkatkan kemampuan pemecahan masalah matematis siswa kelas VII MTs Darul Ulum Sasa pada materi Segitiga.

Penelitian ini menggunakan desain Pra-Experimental. Bentuk desain PraExperimental yang digunakan adalah desain one group pretest-posttest design (Nasir, 2003: 231). Teknik pengambilan sampel yang digunakan adalah purposive sampling yakni teknik penentuan sampel dengan pertimbangan tertentu. Dalam penelitian ini terdapat dua variabel yaitu variabel bebas (X) dan variabel terikat (Y). Variabel bebasnya adalah model pembelajaran kooperatif tipe think-pair-share (TPS) dan variabel terikatnya adalah kemampuan pemecahan masalah matematis yang diperoleh dari hasil posttest.

Teknik pengumpulan data yang digunakan pada penelitian ini yaitu dengan teknik tes. Dalam penelitian ini tes dilakukan dua kali yaitu sebelum (pre-test) dan sesudah (post-test). Tes yang digunakan adalah tes tertulis berbentuk uraian sebanyak 4 soal. Teknik analisis data yang digunakan dalam penelitian ini adalah dengan langkah- langkah sebagai berikut: menetukan rata-rata skor dan simpangan baku, pengujian Gain kemudian dilakukan uji 
normalitas data. Karena data berdistribusi normal maka uji hipotesisnya menggunakan uji paired t test dengan rumus :

$$
t=\frac{\sum d}{\sqrt{\frac{N \sum d_{1}^{2}-\left(\sum d_{1}\right)^{2}}{N-1}}}
$$

Keterangan :

$$
\begin{aligned}
& \mathrm{t}=\text { Nilai } \mathrm{t} \\
& \mathrm{d}=\text { Selisih nilai post dan pre (nilai post }- \text { nilai pre) } \\
& \mathrm{N}=\text { Banyak } \mathrm{n}
\end{aligned}
$$

\section{HASIL PENELITIAN}

Data hasil belajar siswa meliputi data tes preetest dan posttest. Data preetest merupakan hasil belajar siswa sebelum perlakuan yang bertujuan untuk mengetahui hasil belajar siswa sebelum diberikan perlakuan. Data posttest merupakan hasilbelajar siswa setelah perlakuan yang bertujuan untuk mengetahui hasil belajar siswa setelah diberikan perlakuan.

\section{Tes Awal (Pretest)}

Pada saat penelitian siswa kelas VII ${ }^{\mathrm{B}}$ MTs Darul Ulum Sasa sebanyak 25 siswa. Sebelum penerapan model pembelajaran kooperatif tipe Think Pairs Share (TPS), peneliti melaksanakan tes awal. Hasil belajar siswa kelas VII ${ }^{\mathrm{B}}$ MTs Darul Ulum Sasa sebanyak 25 siswa pada tes awal dapat dijabarkan sebagai berikut : Rata-rata hasil tes awal siswa kelas VII ${ }^{\mathrm{B}}$ MTs Darul Ulum Sasa adalah 7,6.

\section{Tes Akhir (Posttest)}

Setelah penerapan model pembelajaran kooperatif tipe Think Pairs Share (TPS), peneliti melaksanakan tes akhir. Hasil belajar siswa kelas VII ${ }^{\mathrm{B}}$ MTs Darul Ulum Sasa pada tes akhir dapat dijabarkan sebagai berikut: Rata-rata hasil tes akhir siswa kelas VII $^{\mathrm{B}}$ MTs Darul Ulum Sasa adalah 11,76. Data hasil preetest dan posttest siswa kelas VII ${ }^{\mathrm{B}}$ MTs Darul Ulum Sasa disajikan pada tabel berikut : 
Tabel 1

Deskripsi data hasil belajar siswa

\begin{tabular}{|c|c|c|}
\hline Deskripsi & Preetest & Postest \\
\hline Rata-rata & 7,6 & $\cdot 11,76$ \\
\hline Nilai minimum & 20,8 & $\cdot 49,92$ \\
\hline Nilai maksimum & 91,52 & $: 87,36$ \\
\hline
\end{tabular}

Data hasil preetest dan postest siswa kelas VII ${ }^{\mathrm{B}}$ MTs Darul Ulum Sasa setelah dikonversikan dalam, disajikan pada tabel berikut :

Tabel 2

\section{Data hasil preetest dan postest siswa kelas VII ${ }^{\mathrm{B}}$ MTs Darul Ulum Sasa Kriteria Penggolongan Kemampuan Pemecahan}

\begin{tabular}{|c|c|c|c|}
\hline \multicolumn{4}{|c|}{ Masalah } \\
\hline \multirow{2}{*}{$\begin{array}{c}\text { Rentangan } \\
\text { Skor }\end{array}$} & \multirow[t]{2}{*}{ Kriteria } & \multicolumn{2}{|c|}{ Jumlah siswa } \\
\hline & & preetest & postest \\
\hline $0-20$ & Sanagat Kurang & - & - \\
\hline $20,1-40$ & Kurang & 2 & - \\
\hline $40,1-60$ & Cukup & 15 & $\cdot 2$ \\
\hline $60,1-80$ & Baik & 7 & . 19 \\
\hline $80,1-100$ & Sangat & 1 & 4 \\
\hline
\end{tabular}

Data yang disajikan pada tabel di atas menunjukkan hasil belajar siswa secara keseluruhan yang dihitung berdasarkan skor total yang diperoleh dari seluruh soal. Pada tes awal (preetest) sebelum diterapkannya model kooperatif tipe (Think Pairs Share) TPS jumlah siswa yang mencapai kualifikasi sangatbaik sebanyak 1 orang, kualifikasi baik sebnayak 7 orang ,kualifikasi cukup sebanyak 15 orang, kualifikasi kurang sebanyak 2 orang. Pada tes akhir (postest) setelah diterapkannya model kooperatif tipe (Think Pairs Share) TPS jumlah siswa yang mencapai kualifikasisangat baik sebanyak 4 orang, kualifikasi baik sebanyak 19 orang, kualifikasi cukup seban yak 2 orang. Deskripsi data tersebut disajikan dalam diagram batang berikut : 


\section{Grafik 1}

\section{Data kualifikasi hasil nilai preetest dan postest secara kes eluruhan}

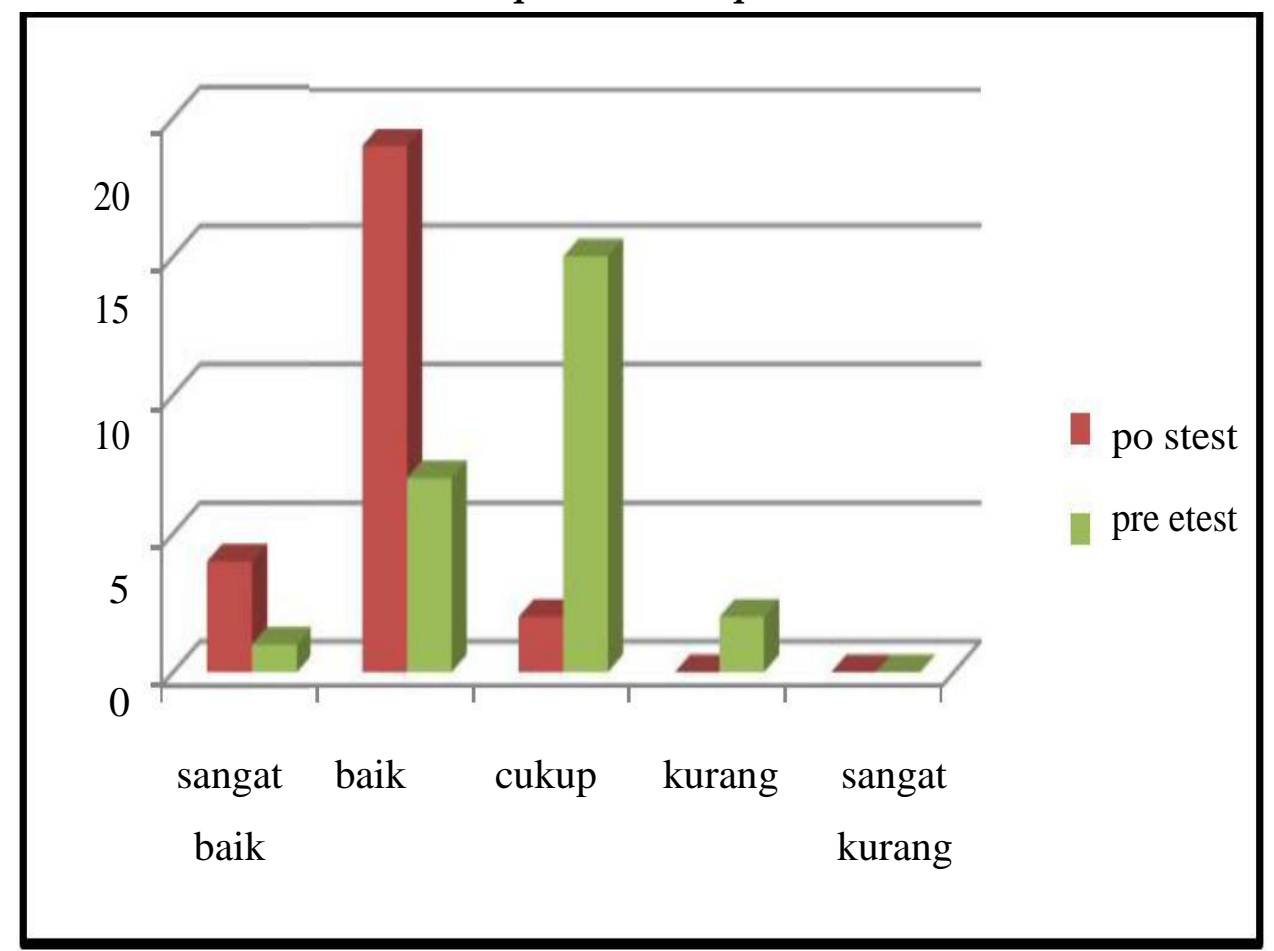

Kemudian untuk peningkatan kemampuan pemecahan masal ah matematis siswa dapat dilihat dari perhitungan Gain (g). Dari hasil perhitu ngan tersebut memiliki peningkatan k emampuan pemecahan masalah sebesar 0,33 dan berada pada kategori sedang.

\section{A. Pengujian Prasyarat Analisis}

Data yang digun akan pada analisis statistik inferensial ini adalah data yang diperoleh setelah perla kuan. Data setelah perlakuan digunakan unt uk melakukan pengujian hipotesis, yaitu mengetahui terdapat peningkatan kemampua $\mathrm{n}$ pemecahan masalah matematis sis wa setelah diterapkannya model pembelajaran Think Pairs Share (TPS). Pengujian persyaratan analisis data yakni uji normalitas dan homogenitas. Uji norm alitas dilakukan untuk mengetahui apakah data berasal dari populasi yang berdistribusi normal atau tidak sedangkan uji homogenitas dilakukan untuk mengetahui apakah kedua kelompok data mempunyai varian yang sama atau tidak.

\section{Uji Normalitas}

Hasil uji normalitas data dengan pemberlakuan model pembelajaran kooperatif tipe TPS menggunakan rumus Chi-Kuadrat diperoleh nilai $x_{\text {hiturg }}^{2}=6.56$ dan $x_{\text {tabel }}^{2}=7.81$. karena $x_{\text {hitrng }}^{2}<x_{\text {tabal }}^{2}$ maka kesimpulannya hasil kemampuan pemecahan masalah matematis siswa berdistribusi normal. 


\section{B. Pengujian Hipotesis}

Dari uji normalitas diketahui data berdistribusi normal, maka statistik uji yang digunakan adalah statistik parametrik dengan menggunakan uji paired $t$ tes, yaitu untuk mengetahui model pembelajaran kooperatif tipe Think-Pairs-Share (TPS) dalam meningkatkan kemampuan pemecahan masalah matematis siswa kelas VII ${ }^{\mathrm{B}}$ MTs Darul Ulum Sasa Kota Ternate, Hasil uji $\mathrm{t}$ diperoleh $\mathrm{t}_{\text {hitung }}=9,99$ dengan taraf signifikan 5\%, dari table $\mathrm{t}$ diperoleh $\mathrm{t}_{\text {tabel }}=1,711$. Dengan demikian dapat disimpulkan bahwa pembelajaran kooperatif tipe Think-Pairs-Share (TPS) dapat meningkatkan kemampuan pemecahan masalah matematis siswa kelas VII ${ }^{\mathrm{B}}$ MTs Darul Ulum Sasa Kota Ternate diterima.

Penelitian dilakukan pada kelas VII $^{\mathrm{B}}$ MTs Darul Ulum Sasa dengan menerapkan model kooperatif tipe TPS guna meningkatkan kemampuan pemecahan masalah matematis, berikut adalah hasil interprestasi dari hasil penelitian.

\section{Kemampuan pemecahan masalah matematis siswa setelah diterapkan model}

\section{Think-Pa irs-Share (TPS)}

Kemampuan pemecahan masalah matematis siswa setela h diterapkan model kooperatif tipe TPS, adapun kemampuan yang diperoleh sisw a yaitu:

a. Mampu mengidentifikasi kecukupan data untuk pemecahan masalah Di bawah ini salah satu hasil kerja siswa ya ng mampu mengidentifikasi kec ukupan data untuk pemecahan masalah:

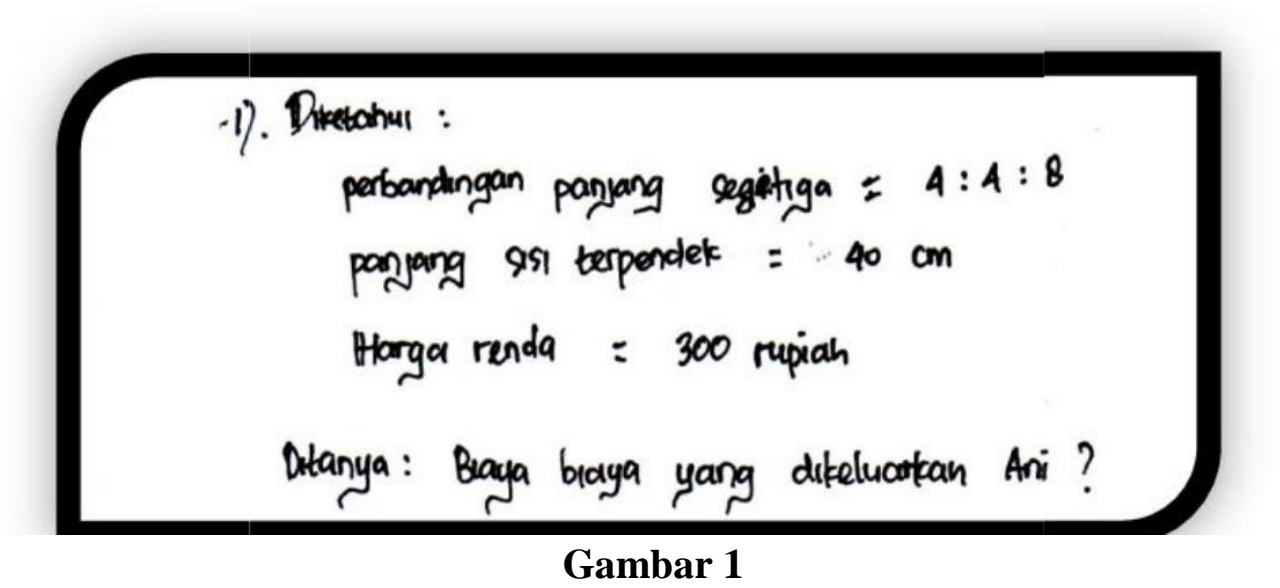

\section{Salah Satu Hasil Pekerjaan Siswa (P1) Mampu Mengidentifikasikan Kecukupan Data}

Berdasarkan hasil kerja siswa di atas, Nampak bahwa jawaban siswa tersebut sudah benar, siswa telah mampu menuliskan unsur-unsur yang diketahui (panjang sisi segitiga, perbandingan sisi-sisi dan harga renda) dan ditanyakan (total biaya). 
b. Memilih dan menerapkan strategi untuk menyelesaikan masala $\mathrm{h}$ (sejenis dan masalah baru) dalam atau di luar matematika.

Di bawah ini salah satu hasil kerja siswa yang mampu memilih dan menerapkan strategi unt uk menyelesaikan masalah (sejenis dan masalah baru) dalam atau di luar matematika :

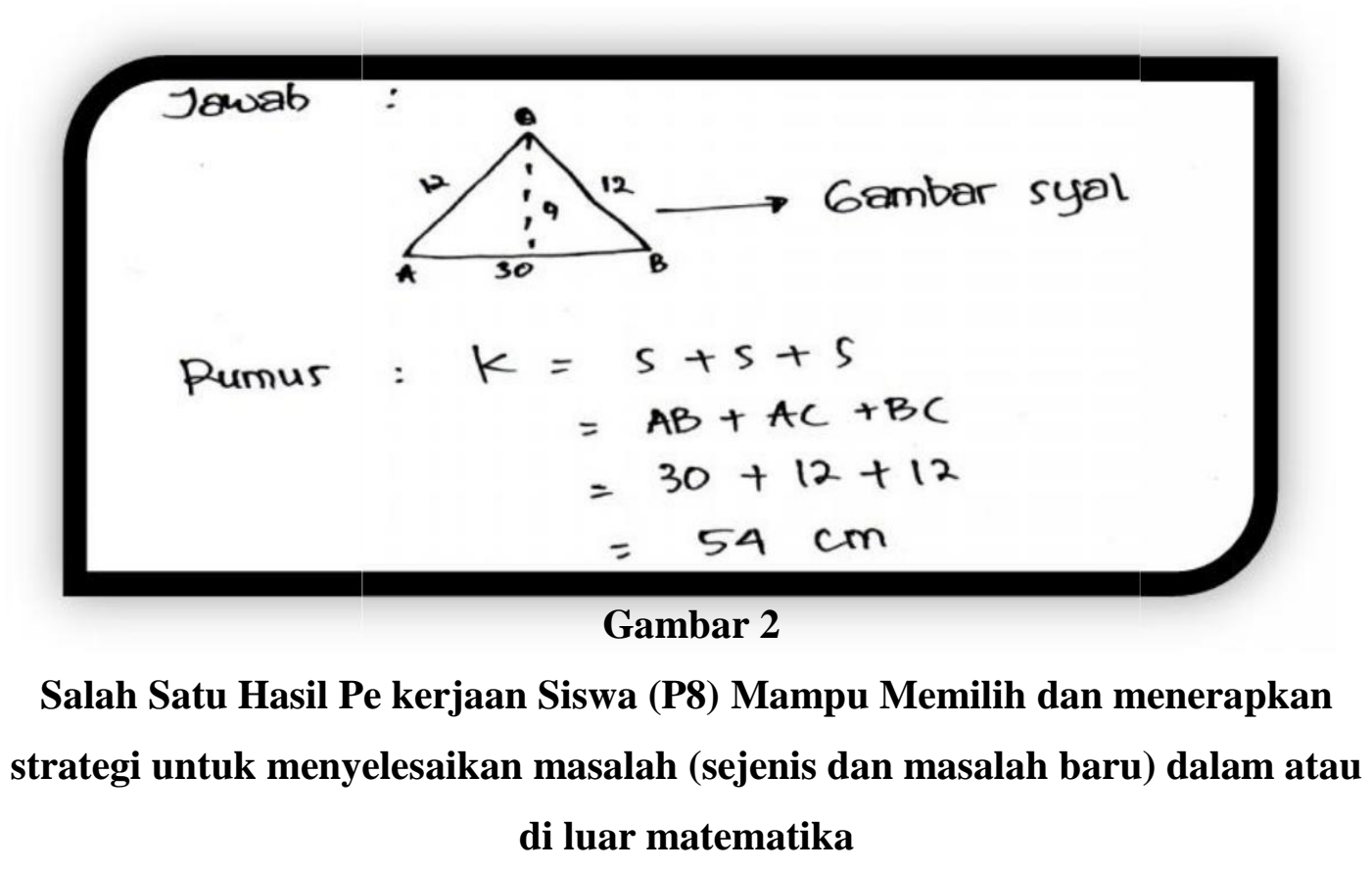

Berdasarkan ha sil kerja dari siswa di atas dapat diketahui bahwa siswa tersebut menyelesaika n masalah dengan melibatkan ekspres i matematis (menggunakan rumus y ang diketahui) dijawab dengan benar meskip un masih ada kekurangan dalam me mberikan satuan pada jawaban akhir (tidak menyebutkan satuan). Keberhasilan siswa pada indikator kedua ini ditunjukukkan karena siswa benar-benar memahami masalah yang disajikan sehingga dapat $m$ enyelesaikan masalah dengan melibatkan ekspresi matematis dan prosedur menjawab dengan benar.

c. Menjelaskan atau menginterprestasi hasil sesuai permasalah an asal serta memeriksa kebenaran hasil atau jawaban

Di bawah ini salah satu hasil kerja siswa yang mampu menjelaskan atau menginterprestasi hasil sesuai permasalahan asal serta memeri ksa kebenaran hasil atau jawaban : 


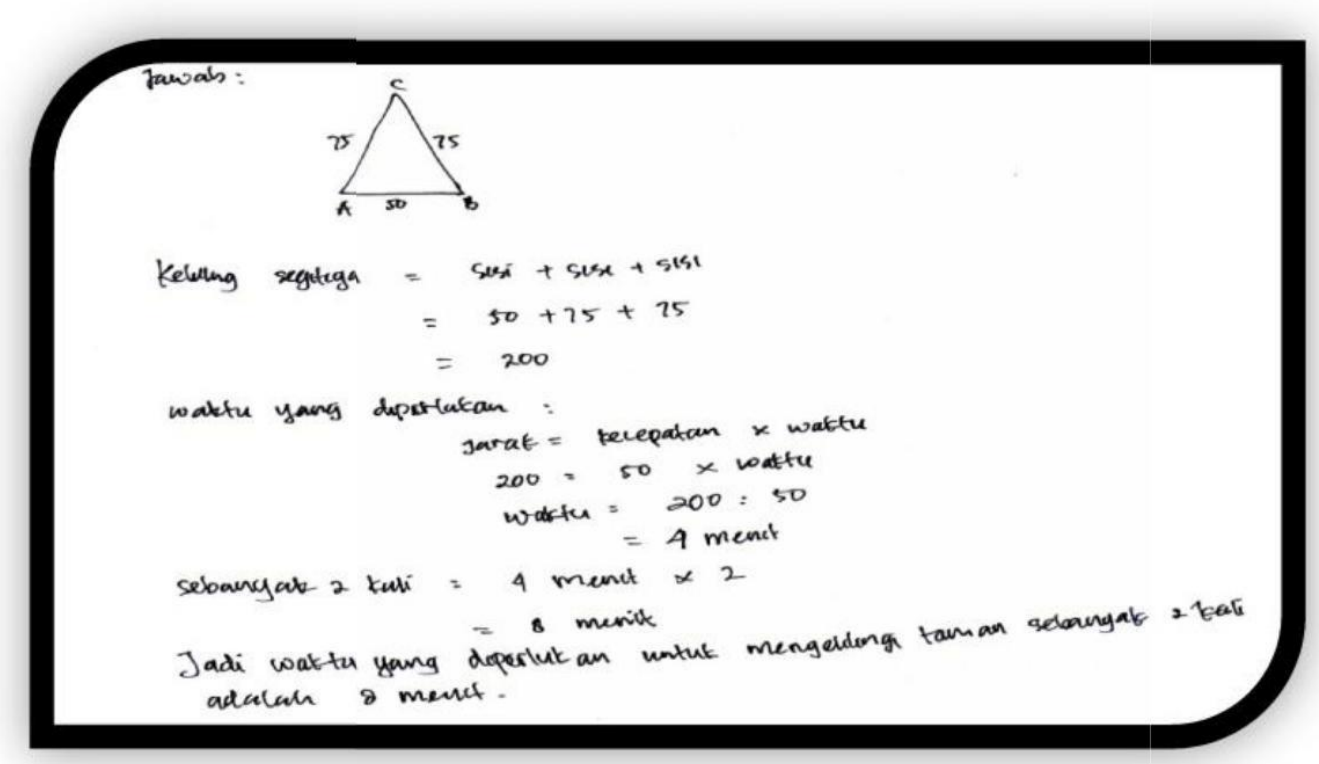

\section{Gambar 3}

\section{Salah satu hasil kerja siswa yang mampu menjela skan atau menginterprestasi hasil sesuai} permasalahan asal serta memeriksa kebenaran hasil atau jawaban

Hasil kerja sisw a di atas, nampak bahwa siswa membuat ga mbar bangun geomteri untuk memperjelas masalah dan penyelesaiannya dikerjakan dengan benar dan tidak ada kesalahan. Siswa mengilustrasikan gambar sesuai dengan masalah yang disajikan. Hal ini karena dalam proses pemecahan masalah berlangsung dalam setiap pasangan siswa sangat aktif untuk berdiskusi. Keberhasilan siswa dalam mengilustrasikan gambar, karena siswa jeli tentang unsur apa yang diketahui dan ditanyakan untuk memecahkan masalah tersebut. 
Berdasarkan hasil pekerjaan siswa di atas menunjukan bahwa sebelum diterapkannya model pembelajaran kooperatif tipe Think-Pairs-Share (TPS) siswa masih belum mampu memecahkan masalah dengan tepat. Dari hasil pekerjaan siswa tersebut dapat dilihat bahwa siswa masih belum mampu mengilustrasikan gambar sesuai dengan masalah yang disajikan. Kemampuan membuat gambar geometri sesuai dengan masalah perlu dikuasai siswa untuk memperjelas masalah dan memfasilitasi penyelesaiannya. Hal tersebutlah yang mengakibatkan siswa mengalami kesalahan dalam menyelesaikan soal tersebut. Tetapi jika dilihat dari hasil kerja siswa setelah diterapkannya model pembelajaran kooperatif tipe ThinkPairs-Share (TPS) di atas, nampak bahwa siswa mampu mengilustrasikan /membuat gambar bangun geomteri untuk memperjelas masalah dan penyelesaiannya dikerjakan dengan benar dan tidak ada kesalahan. Siswa mengilustrasikan gambar sesuai dengan masalah yang disajikan. Hal ini karena dalam proses pemecahan masalah yang berlangsung, siswa terlibat aktif untuk berdiskusi dengan setiap pasangannya.

\section{KESIMPULAN}

Berdasarkan hasil penelitian yang dilakukan, dapat disimpulkan bahwa:

1. Kemampuan pemecahan masalah matematis siswa kelas VII MTs Darul Ulum Sasa setelah menggunakan model pembelajaran kooperatif tipe Think-PairsShare mencapai 73,5\% dari yang sebelumnya hanya mencapai $47,5 \%$

2. Penerapan model pembelajaran kooperatif tipe Think-Pairs-Share dapat meningkatkan kemampuan pemecahan masalah matematis siswa kelas VII MTs Darul Ulum Sasa

3. Peningkatan kemampuan pemecahan masalah matematis siswa kelas VII MTs Darul Ulum Sasa dengan menggunakan model pembelajaran kooperatif tipe Think-Pairs-Share mencapai interprestai sedang. 


\section{DAFTAR PUSTAKA}

Djamarah Syaiful.2010. Guru dan anak didik dalam interaksi edukatif (suatu pendekatan teoritis psikologis. Jakarta: Rineka Cipta

Fauziah Anna. 2010. Peningkatan kemampuan pemahaman dan pemecahan masalah matematis siswa SMP melalui strategi REACT. Forum Pendidikan. Vol. 30 No. 1

Husna,. M. Ikhsan dan Siti Fatimah. 2013. Peningkatan. Kemampuan Pemecahan Masalah dan Komunikasi Matematis Siswa Sekolah Menengah Pertama Melalui Model Pembelajaran Kooperatif Tipe Think-Pair-Share (TPS). Jurnal Peluang. Vol. 1 No. 2

Marlina,. Hajidin dan M. Ikhsan. 2014. Penggunaan Model Pembelajaran Kooperatif Tipe Think-Pair-Share (TPS) untuk Meningkatkan Kemampuan Komunikasi dan Disposisi Matematis Siswa di SMA Negeri 1 Bireuen. Jurnal Didaktik Matematika. Vol. 1, No.1

Nasir Muh. 2003. Metode Penelitian. Jakarta: Ghalia Indonesia

Mufidah Lailatul. 2013. Penerapan model kooperatif tipe TPS untuk meningkatkan aktivitas belajar siswa pada pokok bahasan matriks. Jurnal pendidikan matematika. Vol 1. N

Shoimin aris. 2014. 68 model pembelajaran inovatif dalam kurikulum 2013. Yogyakarta: ARRUZZ Media

Syah Muhaibbin. 2009. Psikologi Belajar. Jakarta : Rajawali Press.

Widya \& Mimin, 2012. Implementasi model pembelajaran kooperatif tipe think pair share untuk meningkatkan aktivitas belajar akuntansi siswa kelas xi ips 1 SMA Negeri 2 Wonosari Tahun ajaran 2011/2012. Jurnal Pendidikan Akuntansi Indonesia, Vol. X, No. 2 